\title{
Prospective comparative study of third trimester serum retinol binding Protein 4 as a potential adipokine marker of pre-eclampsia
}

\section{Üçüncü trimester maternal serum retinol bağlayıc॥ Protein- 4' ün preeklamptik ve normal gebelerde} karşılaştırılması

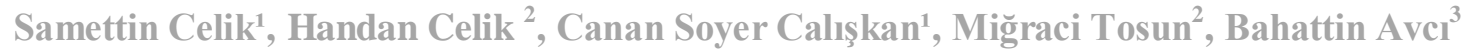

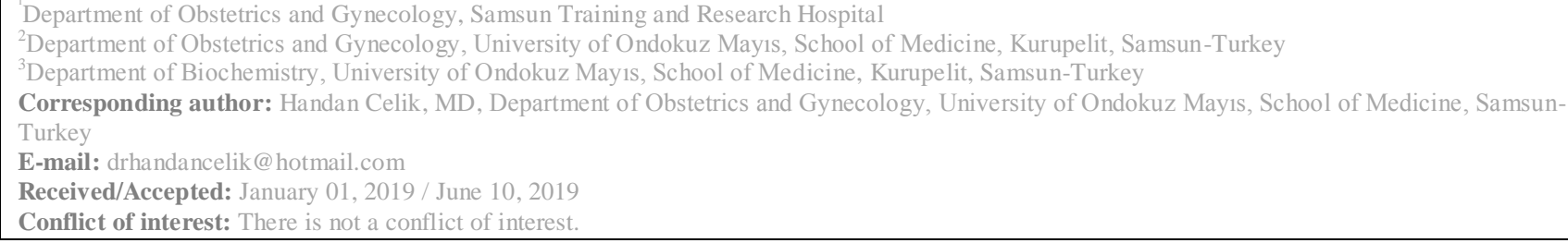

\section{SUMMARY}

Objective: Retinol Binding Protein $-4(\mathrm{RBP}-4)$ is an adipokine that has been identified as a novel regulator of insulin resistance. It has been suggested that insulin resistance might be associated with the pathophysiology of preeclampsia. The aims of this study were to determine whether the maternal serum levels of RBP-4 differ between patients with preeclampsia and those with normal pregnancies and to explore the relationship between the severity of disease and serum concentrations of RBP-4.

Method: This case-control study included two groups: 1. Patients with preeclampsia $(n=27)$ and 2. Patients with normal pregnancies $(n=27)$. All subjects enrolled in the study were in their gestational age of 30 weeks or more. Serum RBP-4 concentrations were determined by ELISA.

Results: Patients with preeclampsia had a higher serum concentration of RBP-4 than that of normal pregnant women ( $p<0.001)$. When women with preeclampsia were categorized as those with preeclampsia and severe preeclampsia, no significant difference was observed in the concentration of serum RBP-4 $(\mathrm{p}=0.272)$.

Conclusions: Our results support a role of RBP-4 in the pathogenesis of preeclampsia

Keywords: Preeclampsia, insulin resistance, retinol binding protein-4

ÖZET

Amaç: Retinol Binding Protein-4 (RBP-4) insulin reziztansında düzenleyici olan yeni bir adipokindir. İnsülin reziztansının preeklampsi patofizyolojisinde rolü olabileceği düşünülmektedir. Bu çalışmamızdaki amacımız preeklampsi hastalarında RBP-4'inin serum seviyelerinin sağlıklı gebelere göre farklı olup olmadığını tespit etmektir. Yöntem: Vaka kontrollü bu çalışmada 27 preeklamptik ve 27 sağl1klı gebede serum RBP-4 değerleri ELISA yöntemi ile çalış1lı. Gebelerin tümünün gebelik haftası 30 hafta ve üzerinde idi.

Bulgular: Preeklamptik gebelerde serum RBP-4 seviyesi sağlıklı gebelerden anlamlı olarak yüksek bulundu (p < 0.001). Şiddetli preeklampsi grubunda, diğer preeklampsi hastalarına göre anlamlı fark yoktu. 
Sonuç: Yeni bir adipokine olan RPB-4 'ün preeklampsi fizyopatogenezin rol oynadığı yönünde sonuca varılmıştır. Ancak preeklampsinin șiddeti ile RBP-4 arasında ilișki bulunamamıștır.

Anahtar sözcükler: Preeklampsi, insülin rezistans1, RBP-4

\section{INTRODUCTION}

Preeclampsia is a severe complication of pregnancy characterized by hypertension and proteinuria ${ }^{(1)}$. It is a leading cause of maternal and fetal mortality and morbidity ${ }^{(}{ }^{\text {) }}$. Despite intensive efforts, the exact pathogenesis of preeclampsia is still unknown. Because of its syndromic nature, several mechanisms and conditions, such as the abnormal transformation of spiral arteries, endothelial dysfunction, chronic uteroplacental ischemia, and dysregulation of angiogenic and anti-angiogenic factors, are associated with preeclampsia and its clinical features $\left(3^{-5}\right)$. Preeclampsia shares features of metabolic syndrome, including insulin resistance, obesity, and dyslipidemia ( $1-6)$. Pregnancy complicated by preeclampsia significantly increases the risk of cardiovascular disease for the mother ${ }^{(1)}$. It has been well documented that insulin resistance is a physiological state of pregnancy that increases gradually reaching a peak in the third trimester of pregnancy. Adipokines may participate in the establishment of insulin resistance. Several investigations have proved that preeclampsia is a state of exaggerated insulin resistance and is associated with adipokine changes $(7-8)$

Adipokines are adipocyte-derived biologically active cytokines/hormones that are secreted from adipocytes and include leptin, adiponectin, resistin, visfatin, and cytokines such as tumor necrosis factor alpha (TNF- $\alpha$ ), interleukin-6, interleukin -1, and monocyte chemotactic protein$1^{(9)}$. Adipokines regulate glucose metabolism and insulin sensitivity and play roles in obesity, dyslipidemia, and insulin resistance $\left.{ }^{(}{ }^{10}\right)$ and are expressed in the human placenta $^{(11)}$. In preeclampsia, dysregulation of circulating adipokines such as TNF- $\alpha$, visfatin, adiponectin, and leptin affects insulin sensitivity leading to insulin resistance ${ }^{\left({ }_{12}\right)}$.

Retinol-binding protein-4 (RBP-4) is a recently identified novel adipokine that is upregulated in conditions of insulin resistance and obesity ( 14 ) . Elevated RBP-4 levels increase the hepatic glucose output and insulin resistance ( $1^{4}$ ). Elevated serum levels of RBP-4 were demonstrated in patients with impaired glucose tolerance and diabetes mellitus type $2\left(1^{4}-15\right)$. Moreover, it was reported that serum RBP-4 levels increase during pregnancy in patients with gestational diabetes mellitus $(16-17)$.

Although alterations in the serum levels of adipokines were demonstrated in preeclampsia, there are only a few reports, with conflicting results, about the potential role of RBP-4 in patients with preeclampsia $(18-22)$. In this study, we evaluated the maternal serum RBP-4 levels in preeclamptic patients and compared them with serum RBP-4 levels in normal pregnant women. We aimed to obtain insight into the role of RBP-4 in the development and pathogenesis of preeclampsia.

\section{MATERIAL AND METHODS}

This case-control study was conducted at Ondokuz Mayis University, Department of Obstetrics and Gynecology. Twenty-seven pregnant women with preeclampsia and 27 healthy pregnant women were recruited. Preeclampsia was defined as a blood pressure of 140/90 mm Hg or higher on 2 occasions at least 6 hours apart, occurring after 20 weeks' gestation and accompanied by proteinuria (proteinuria was defined as $\geq 300 \mathrm{mg} / 24$ hours or $\geq+1$ by dipstick in a random urine analysis) ${ }^{(9)}$. Preeclampsia was categorized as severe if the systemic blood pressure was $160 / 110 \mathrm{mmHg}$ or more on two occasions 6 hours apart or the presence of severity evidence like visual disturbances, upper abdominal pain, convulsion, oliguria, headache, elevated serum liver enzyme or serum creatinine, thrombocytopenia. Exclusion criteria included the presence of diabetes mellitus, chronic hypertension, multiple gestations, fetal anomalies, polyhydramnios, intrauterine death, active labor, premature rupture of membrane, maternal autoimmune disease, and other systemic diseases. All patients had a normal glucose tolerance test performed at the gestational age of 24-28 weeks. To avoid possible bias, samples taken from the healthy pregnant women were matched with that from preeclamptic patients in terms of gestational age. All subjects enrolled in the study were in their gestational age of 30 weeks or more. The study was approved by the institutional ethics committee, and all participants provided informed consent prior to blood collection.

Blood samples were collected from patients with preeclampsia at the time of diagnosis of the disease and before starting any medication. Blood 
samples were obtained from controls after admittance to the obstetrics department for delivery or from patients admitted to the outpatient clinic.

Plasma serum was extracted, aliquoted, and stored at $-40{ }^{\circ} \mathrm{C}$. Serum RBP-4 concentration $(\mu \mathrm{g} / \mathrm{ml})$ was measured using the commercially available Sandwich ELISA kit (Cat No. EZH RBP-4-18K; Millipore MA, USA). Enzymatic reactions were quantified in an automatic microplate photometer. The lower limit of detection was $0.14 \mu \mathrm{g} / \mathrm{ml}$. The mean interassay coefficient of variation $(\mathrm{CV}) \%$ and intraassay CV\% for RBP-4 were $3.34 \%$ and $3.77 \%$, respectively. Assays were conducted according to the manufacturers' instructions. The samples were measured in duplicate.

All values were expressed as the mean $\pm \mathrm{SD}$. Oneway ANOVA was used to compare means among groups. The Mann-Whitney- $U$ and Kruskal-Wallis tests were used for comparisons of continuous variables. Statistics package, SPSS (Statistical Analysis System, Chicago, IL, USA), was used for data analysis. Values of $p<0.05$ were considered statistically significant.

\section{RESULTS}

Table 1 displays the demographic and clinical characteristics of the study groups. There was no significant difference in baseline characteristics such as age BMI and gravidity between women with preeclampsia $(\mathrm{n}=27)$ and those with uncomplicated pregnancy $(\mathrm{n}=27)$. The mean age of women with preeclampsia and women with uncomplicated pregnancy was $30 \pm 5.7$ and $29 \pm$ 5.9 years, respectively. Gestational age at delivery was significantly shorter in the preeclampsia group than in the control group $(\mathrm{p}=0.007)$.

Table 1: Characteristics of the entire study population

\begin{tabular}{|c|c|c|c|}
\hline & $\begin{array}{l}\begin{array}{l}\text { Preeclampsia group } \\
(\mathrm{n}=27)\end{array} \\
\text { Mean } \pm \text { SD } \\
\text { Median (Min-Max)* }\end{array}$ & $\begin{array}{l}\text { Control group }(\mathrm{n}=27) \\
\text { Mean } \pm \text { SD } \\
\text { Median (Min-Max)* }\end{array}$ & $\mathrm{p}$ \\
\hline Age (years) & $30.59 \pm 5.73$ & $29.00 \pm 5.96$ & 0.322 \\
\hline BMI $(\mathrm{kg} / \mathrm{m} 2)$ at sampling & $28.76 \pm 2.12$ & $27.97 \pm 2.67$ & 0.236 \\
\hline Gravidity & $1(1-5) *$ & $2(1-6) *$ & 0.698 \\
\hline $\begin{array}{l}\text { Gestational age at blood } \\
\text { sampling (week) }\end{array}$ & $37(30-41) *$ & $37(31-40) *$ & 0.794 \\
\hline $\begin{array}{l}\text { Gestational age at delivery } \\
\text { (week) }\end{array}$ & $37(30-41) *$ & $39(35-40) *$ & $0.007 * *$ \\
\hline Birth weight $(\mathrm{kg})$ & $2477 \pm 828$ & $3138 \pm 474$ & $0.001 * *$ \\
\hline Systolic Pressure (mmHg) & $170(150-190) *$ & $120(130-80) *$ & $0.001 * *$ \\
\hline Diastolic Pressure ( $\mathrm{mmHg}$ ) & $110(100-130) *$ & $70(50-80) *$ & $0.001 * *$ \\
\hline
\end{tabular}

Gestational ages at blood sampling were not different between the preeclampsia and control groups. Systolic and diastolic blood pressure was significantly different between subjects with preeclampsia and the controls $(\mathrm{p}<0.001)$. In the preeclampsia group, mean serum RPB4 levels were significantly higher than in the control group $(27.38 \pm 7.14 \mu \mathrm{g} / \mathrm{ml}$ vs. $15.45 \pm 4.52 \mu \mathrm{g} / \mathrm{ml}$, respectively, $\mathrm{p}<0.001)$.
When women with preeclampsia were categorized as those with preeclampsia and severe preeclampsia, no significant differences in maternal age, BMI, gestational age at the time of blood sampling, and delivery were observed ( $\mathrm{p}>$ 0.05). In the severe preeclampsia group, systolic and diastolic pressure was significantly higher than that in the preeclampsia group $(\mathrm{p}<0.05)$ (Table 2). Moreover, birth weight was significantly lower in the severe preeclampsia 
group than in the control group $(\mathrm{p}=0.002)$. Serum RBP-4 concentration did not differ significantly between women with severe preeclampsia and those with preeclampsia $(26.20$ $\pm 6.89 \mu \mathrm{g} / \mathrm{ml}$ vs. $29.38 \pm 7.47 \mu \mathrm{g} / \mathrm{ml}$, respectively, $\mathrm{p}=0.272)($ Table 3$)$.

Table 2: Characteristics of preeclampsia subgroups

\begin{tabular}{|l|l|l|l|}
\cline { 2 - 4 } \multicolumn{1}{l|}{} & $\begin{array}{l}\text { Severe Preeclampsia } \\
(\mathrm{n}=17) \\
\text { Mean } \pm \text { SD } \\
\text { Median (Min-Max)* }\end{array}$ & $\begin{array}{l}\text { Preeclampsia } \\
(\mathrm{n}=10) \\
\text { Mean } \pm \text { SD } \\
\text { Median (Min- } \\
\text { Max)* }\end{array}$ & $\mathrm{p}$ \\
\hline Age (years) & $30.47 \pm 6.12$ & $30.80 \pm 5.30$ & 0.889 \\
\hline Gravidity & $1(1-5)$ & $1(1-4)$ & 0.488 \\
\hline BMI (kg/m2) at sampling & $28.41 \pm 2.25$ & $29.35 \pm 1.82$ & 0.278 \\
\hline $\begin{array}{l}\text { Gestational age at blood sampling } \\
\text { (week) }\end{array}$ & $35.76 \pm 3.41$ & $36.70 \pm 2.98$ & 0.479 \\
\hline $\begin{array}{l}\text { Gestational age at delivery } \\
\text { (week) }\end{array}$ & $35.76 \pm 3.41$ & $36.70 \pm 2.98$ & 0.479 \\
\hline Birth weight (kg) & $2369 \pm 878$ & $2660 \pm 762$ & 0.389 \\
\hline Systolic Pressure (mmHg) & $170(150-190) *$ & $160(140-160) *$ & $\mathbf{0 . 0 3 8 * *}$ \\
\hline Diastolic Pressure (mmHg) & $110(100-130) *$ & $100(100-120) *$ & $\mathbf{0 . 0 4 6 * *}$ \\
\hline
\end{tabular}

* Median values

$* * \mathrm{p}<0.05$

Table 3: Retinol Binding Protein-4 (RBP-4) in preeclampsia and control groups and in preeclampsia subgroups

\begin{tabular}{|l|l|l|l|}
\cline { 2 - 4 } \multicolumn{1}{c|}{} & $\begin{array}{l}\text { Preeclampsia }(\mathrm{n}=27) \\
\text { Mean } \pm \text { SD }\end{array}$ & $\begin{array}{l}\text { Controls }(\mathrm{n}=27) \\
\text { Mean } \pm \text { SD }\end{array}$ & $\mathrm{p}$ \\
\hline RBP-4 (ng/mL) & $27.38 \pm 7.14$ & $15.45 \pm 4.52$ & $\mathbf{0 . 0 0 1 *}$ \\
\hline
\end{tabular}

\begin{tabular}{|l|l|l|l|}
\cline { 2 - 4 } & $\begin{array}{l}\text { Severe Preeclampsia } \\
(\mathrm{n}=17) \\
\text { Mean } \pm \text { SD }\end{array}$ & $\begin{array}{l}\text { Preeclampsia } \\
(\mathrm{n}=10) \\
\text { Mean } \pm \text { SD }\end{array}$ & $\mathrm{p}$ \\
\hline RBP-4 (ng/mL) & $26.20 \pm 6.89$ & $29.38 \pm 7.47$ & 0.272 \\
\hline
\end{tabular}




\section{DISCUSSION}

In this study, we found that the circulating RBP-4 concentrations increased in preeclamptic women compared with the controls. All patients who developed preeclampsia, irrespective of disease severity, showed significantly higher serum levels of RBP-4 than the controls. These findings suggest an association between RBP-4 and the pathophysiology of preeclampsia. However, we did not find any difference in the serum concentrations of RBP-4 in patients with severe preeclampsia.

Beginning with the second trimester of pregnancy, physiological insulin resistance develops in pregnant women ${ }^{(23)}$. Human placental lactogen and placental growth hormone are placental hormones related to the development of insulin resistance $\left({ }_{24}\right)$. In recent years, the roles of adipokines (such as visfatin, leptin, adiponectin, and vaspin) were studied in preeclampsia and gestational diabetes $\left(13,2_{11}, 2_{2}-2^{7}\right)$.

In recent years, it has been suggested that insulin resistance and hyperinsulinemia might also be associated with the pathophysiologic mechanisms of preeclampsia ( 6 ) . There is growing evidence that insulin resistance may play a role in the development of endothelial damage $\left({ }^{28}\right)$. It has been reported that in non-pregnant adults with essential hypertension, insulin sensitivity decreased, and there was a positive correlation between the degree of insulin resistance and the severity of hypertension $\left({ }^{29}\right)$. RBP-4 was introduced as a novel insulin resistance-inducing adipokine that increases in obesity and insulin resistance $\left({ }^{10}, 1_{4}\right)$. To the best of our knowledge, there are only 5 reports describing the relationship between preeclampsia and RBP-4, but these reports showed conflicting results $(18-22)$. Stephan et al. reported that circulating serum RBP-4 levels were not significantly different between preeclampsia patients and healthy controls of similar gestational age $\left({ }^{18}\right)$. In contrast, Shangguan et al., and Inoue et al., demonstrated that circulating concentrations of RBP-4 increased in preeclamptic women compared with controls $(14)$. Shangguan et al. also stated that the serum levels of RBP-4 did not change significantly in women in late pregnancy as compared to non-pregnant women, and serum concentrations of RBP-4 increased significantly in women with severe preeclampsia compared to those with mild preeclampsia ${ }^{(21)}$. In the current investigation, there was a significant difference in the serum concentrations of RBP-4 between preeclampsia and controls, and hence, the serum level of RBP-4 was not related to the severity of preeclampsia.

Interestingly, in a recent study, serum RBP-4 levels were significantly higher in overweight patients with late-onset preeclampsia than in women of normal weight with late-onset preeclampsia and overweight controls ( ${ }^{20}$ ) . In contrast, another recent study of preeclamptic women and controls suggested that both maternal and umbilical cord serum RBP-4 levels in the third trimester of pregnancy were significantly lower in women with preeclampsia than in the controls ${ }^{(30)}$.

In conclusion, we demonstrated that maternal RBP-4 levels significantly increase in preeclampsia, suggesting that an increase in RBP4 serum concentration is important in the pathophysiology of preeclampsia. However, further studies are required to determine the exact role of RBP-4 in preeclampsia.

\section{REFERENCES}

1. Sibai B, Dekker G, Kupferminc M. Preeclampsia. Lancet 2005; 365: 785-799

2. Dekker GA, Sibai BM. Etiology and pathogenesis of preeclampsia: current concepts. Am J Obstet Gynecol 1998; 179: 1359-1375.

3. Chaiworapongsa T, Romero R, Kim YM, Kim GJ, Kim MR, Espinoza J, et al. Plasma soluble vascular endothelial growth factor receptor-1 concentration is elevated prior to the clinical diagnosis of preeclampsia.J Matern Fetal Neonatal Med 2005;17:3-18.

4. Levine RJ, Lam C, Qian C, Yu KF, Maynard SE, Sachs BP, et al. Soluble endoglin and other circulating antiangiogenic factors in preeclampsia. N Engl J Med 2006;355:992-1005

5. Romero R, Nien JK, Espinoza J, Todem D, Fu $\mathrm{W}$, Chung $\mathrm{H}$, et al. A longitudinal study of angiogenic (placental growth factor) and antiangiogenic (soluble endoglin and soluble vascular endothelial growth factor receptor-1) factors in normal pregnancy and patients destined to develop preeclampsia and deliver a small for gestational age neonate. J Matern Fetal Neonatal Med 2008;21:9-23.

6. Solomon CG, Seely EW. Brief review: hypertension in pregnancy : a manifestation of the insulin resistance syndrome? Hypertension 2001;37:232-239.

7.Roberts JM,GammillHS. Preeclampsia: recent insights.Hypertension 2005;46:1243-9. 
8. Redman CW, Sargent IL. Latest advances in understanding preeclampsia. Science

2005;308:1592-1594.

9. ACOG practice bulletin. Diagnosis and management of preeclampsia and eclampsia. 2002. Obstet Gynecol 2002; 99:159-167.

10. Yang Q, Graham TE, Mody N, Preitner F, Peroni OD, Zabolotny JM, et al. Serum retinol binding protein 4 contributes to insulin resistance in obesity and type 2 diabetes. Nature 2005;436:356-362.

11. Zavalza-Gomez AB, et al. Adipokines and insulin resistance during pregnancy.

Diabetes Res Clin Pract 2008;80:8-15.

12. Vaisbuch E, Romero R, Mazaki-Tovi S, Erez $\mathrm{O}$, Kim KS, Chaiworapongsa $\mathrm{T}$ et al. Retinol binding protein 4 - a novel association with earlyonset preeclampsia. J Perinat Med 2010, 38(2): 129-139.

13. Miehle K, Stepan H and Mathias Fasshauer. Leptin, adiponectin and other adipokines in gestational diabetes mellitus and pre-eclampsia. Clinical Endocrinology 2012; 76: 2-11.

14.Graham TE, Yang Q, Bluher M, Hammarstedt A, Ciaraldi TP, Henry RR. Retinol-binding protein 4 and insulin resistance in lean, obese, and diabetic subjects. N Engl J Med 2006;354:25522563.

15. Cho YM, Youn BS, Lee H, Lee N, Min SS, Kwak SH et al. Plasma Retinol Binding Protein-4 concentrations are elavated in human subjects with impaired glucose tolerance and type 2 diabetes. Diabetes Care 2006; 29: 2457-2461.

16. Chan TF, Chen HS, Chen YC, Lee CH, Chou $\mathrm{FH}$, Chen IJ, et al. Increased serum retinolbinding protein 4 concentrations in women with gestational diabetes mellitus. Reprod Sci 2007;14:169-174.

17. Klein K, Todesca DB, Leipold H, Knöfler M, Haslinger P, Handisurya A. Retinol Binding Protein 4 in Patients with Gestational Diabetes Mellitus. J of Women's Health 2010; 19: 517-521.

18. Stepan, H., Ebert, T., Schrey, S. et al. Preliminary report: serum levels of retinol-binding protein 4 in preeclampsia. Metabolism 2009; 58: 275-277.

19. Kholy AA, Abadier MZ, Rageh EM, Kallaf HE. Seeum levels of placental growth factor and retinol binding protein-4 in pregnancy induced hypertensive women. J Am Science 2010; 6: 448-
455.

20. Masuyama, H., Inoue, S. \& Hiramatsu, Y. Retinol-binding protein 4 and insulin resistance in preeclampsia. Endocrine Journal, 2011; 58: 4753.

21. Shangguan, X, Liu F, Wang H, He J, Dong M. Alterations in serum adipocyte fatty acid binding protein and retinol binding protein-4 in normal pregnancy and preeclampsia. Clinica Chimica Acta 2009; 407: 58-61.

22. Inoue S, Takamoto, N., Akahori, Y, Akahori Y, Masumoto A, Nakatsukasa H. Elevated level of serum retinol-binding protein 4 in pregnancyinduced hypertension.. The Journal of Obstetrics and Gynaecology Research 2009; 35: 293-300.

23. Catalano PM, et al. Longitudinal changes in glucose metabolism during pregnancy in obese women with normal glucose tolerance and gestational diabetes mellitus. Am J Obstet Gynecol 1999;180:903-16.

24. Barbour LA, et al. Human placental growth hormone causes severe insulin resistance in transgenic mice. Am J Obstet Gynecol 2002;186:512-7.

25. Nanda, S, Yu, C.K, Giurcaneanu. Maternal serum adiponectin at 11-13 weeks of gestation in preeclampsia. Fetal Diagnosis and Therapy 2011; 29: 208-215.

26. Mazaki-Tovi, S., Vaisbuch, E., Romero, R. Maternal and neonatal circulating visfatin concentrations in patients with pre-eclampsia and a small-for-gestational age neonate. The Journal of Maternal-Fetal \& Neonatal Medicine 2010; 23: 1119-1128.

27. Moore, L.E., Wallace, K.L., Alexander, B.T. Reduced placental perfusion causes an increase in maternal serum leptin. Placenta 2003; 24: 877881.

28. Haffner S. Epidemioliogy of hypertension and insulin resistance syndrome. J hypertens 1997; 15: 25-30.

29. Ferrannini E, Buzzigoli G, Bonadonna R et al. Insulin resistance in essential hypertension. Diabetes Care 2004; 27: 274-275.

30. Seol, H.J., Kim, J.W. \& Kim, H.J. Retinolbinding protein- 4 is decreased in patients with preeclampsia in comparison with normal pregnant women. Journal of Perinatal Medicine 2011; 39: 287-289. 